\title{
Üniversite Öğrencilerinin Sosyal Medya Platformlarındaki Politik Mesajlara Tepkileri; Düzce Üniversitesi Sosyal Bilimler Meslek Yüksekokulu'nda Yapılan Kantitatif Bir Araştırma*
}

\author{
Ömer Faruk Özgür (Öğr. Gör. Dr.) \\ Düzce Üniversitesi Sosyal Bilimler Meslek Yüksekokulu \\ omerfarukozgur@gmail.com
}

ORCID: 0000-0001-5263-2403

Başvuru Tarihi: 19.07.2019

Yayına Kabul Tarihi: 04.11.2019

Yayınlanma Tarihi: 24.01.2020

DOI: http://10.17680/erciyesiletisim.594243

\section{Öz}

Sosyal medya yeni iletişim teknolojilerinin ortaya çıkmasıyla hayatımıza girmiştir ve özellikle gençlerin sanal dünyalarının özü haline geldiği genel kabul görmektedir. Çeşitli araştırmalar, gençlerin gittikçe artan bir şekilde kendini tanıtmak, kişilerarası iletişim kurmak, günlük olaylardan haberdar olmak ve fikirlerini ifade etmek için yoğun olarak sosyal medya platformlarını kullandığını göstermektedir. Çalışmanın Amacı: $\mathrm{Bu}$ araștırma üniversite öğrencilerinin internet ve sosyal medya kullanım alışkanlıklarını ortaya koymayı ve bu bağlamda sosyal medya platformlarında dolaşan siyasi paylaşımlara yaklaşımlarını araştırmayı amaçlamaktadır. $\mathrm{Bu}$ amaçla Düzce Üniversitesi Sosyal Bilimler Meslek Yüksekokulu'ndan 420 öğrenciden oluşan bir örneklem çalışmaya dâhil edilmiş ve bu grupla yüz yüze anket çalışması yapılmıştır. Yöntem: Çalışma kapsamında kantitatif araştırma tekniklerinden yüz yüze anket tekniği kullanılmıștır. Çalışma \%98 güven düzeyi ve $\% 5$ hata payı ile yapılmıştır. Bulgular: Araştırmanın ana bulgularından biri, internetin gençlerin günlük yaşamlarında, ilk sırada sosyal medya platformları kullanımı amacı ile (\%46) sonra araştırma amacı ile $(\% 19,4)$, sosyal etkileşimde bulunma veya birbirleriyle iletişim kurma amacı ile $(\% 10,2)$ kullanılan önemli bir araç olduğu sonucudur. Siyasal iletişim ve sosyal medya bağlamında, öğrenciler politik mesajlara mesafeli görünmelerine rağmen, bunun yanında öğrencilerin gözünde sosyal medya platformları siyasal iletişim açısından önemli bir araç olarak görülmektedir. Sosyal medya platformlarında genç yetişkinlerin yarısından fazlası, özellikle siyasî paylaşımlara yorum yapmak ve onlarla etkileşimde bulunmak yerine siyasetçilerin takipçileri konumunda bulunmaktadırlar. Her ne kadar araştırmanın bulguları tüm üniversite öğrencileri için genelleştirilemese de bu pilot çalışma gençlerin sosyal medya platformlarında politik mesajlara tepkilerini anlama konusunda anlamlı veriler sağlama potansiyeline sahiptir.

Anahtar Kelimeler: Sosyal Medya, Üniversite Öğrencileri, Siyasî Paylaşımlar, İnternet Kullanımı, Siyasal İletişim.

\footnotetext{
* Bu çalışma Kocaeli Üniversitesi Sosyal Bilimler Enstitüsü'ne 2013 yılında sunulan "Siyasal İletişim ve Sosyal Medya Kullanımı: Düzce Üniversitesi Sosyal Bilimler Meslek Yüksekokulu Öğrencileri Üzerinde Bir Araştırma” başlıklı yüksek lisans tezinden türetilmiş makaledir.
} 


\title{
The Reactions of University Students on Political Messages in Social Media Platforms; A Quantitative Research at the Duzce University Vocational School of Social Sciences
}

\author{
Ömer Faruk Özgür (Lect. Ph.D.) \\ Duzce University Vocational School of Social Sciences \\ omerfarukozgur@gmail.com \\ ORCID: 0000-0001-5263-2403
}

Date Received: 19.07.2019

Date Accepted: 04.11.2019

Date Published: 24.01.2020

DOI: http://10.17680/erciyesiletisim.594243

\begin{abstract}
Social media have entered our lives with the emergence of new communication technologies and it is generally accepted that young people have become the essence of their lives. Various research shows that young people are increasingly using social media platforms to promote themselves, to communicate with people, to be aware of daily news and to express their ideas. Objective of the Study: This study aims to reveal the applications of internet and social media usage of university students and to investigate their approaches to various political shares seen in social media platforms. For this purpose, a sample of 420 students from Düzce University Vocational School of Social Sciences was included in the study and a survey was conducted with this group. Method: Face to face questionnaire technique was used as a quantitative research method. The study was conducted with $98 \%$ confidence level and 5\% error margin. Results: One of the main findings of the study was that internet was used first in the daily lives of young people for the use of social media platforms (46\%), then for research (19.4\%), for social interaction or for communication with each other $(10.2 \%)$. reveals that it is an important tool. In the context of political communication and social media, although students seem distant to political messages, social media platforms are seen as an important tool for political communication in the eyes of students. On social media platforms, more than half of young adults are politicians' followers, rather than commenting and interacting with political posts. Although the findings of the research cannot be generalized for all university students, this pilot study has the potential to provide meaningful data on understanding their response to political messages on social media platforms.
\end{abstract}

Keywords: Social Media, University Students, Political Posts, Internet Usage, Political Communication. 


\section{Giriş}

İnsanoğlunun hayatında çok önemli bir yeri olan iletişim kavramını farklı disiplinler farklı şekillerde tanımlamışlardır. Bu manada iletişime ilişkin 400'e yakın tanımlama yapılmıştır. Bir görüş olarak bu kadar fazla tanımlama yapılmasının temelinde iletişim alanının çok geniş olması ve her disiplinin kendi bakış açısına uygun olarak iletişimi algılaması ve tanımlaması yatmaktadır denilebilir. Felsefe ile ilgilenenler iletişimin felsefi boyutunu daha ön plana çıkarırken, tarihçiler tarihteki rolünü, dil bilimciler ise dil ve gelişimi üzerindeki katkısını ön plana çıkarmışlardır. Bu sebeple çok farklı iletişim tanımları ortaya çıkmıştır.

Berelson ve Steiner iletişimi şu șekilde tanımlamışlardır : "İletişim bilginin, fikirlerin, duyguların, becerilerin vb. simgeler kullanılarak aktarılmasıdır"(Mutlu, 1994, s.141). Bu tanımlamada iletişimin bilgi, duygu, düşünce paylaşımı boyutu üzerinde durulmuştur. İnsanlar kimi zaman iletişim kurarken bilgi aktarırlar, kimi zaman duygularını kimi zaman da bir konu hakkındaki düşüncelerini karşı tarafa çeşitli araçlarla aktarırlar.

Diğer bazı tanımlarda iletişim şu şekilde ifade edilmiştir: Enformasyon, düşünce, tutum veya duyguların bir kişiden veya gruptan ötekine(veya diğerlerine) özellikle semboller aracılığı yoluyla iletilmesidir (Theodorson ve Theodorson, 1969). En genel anlamıyla; bir sistem, bir kaynak, bir ötekini hedefini, alternatif sembolleri ele alıp bunları ikisini birleștiren kanaldan ileterek, manipüle ederek etkilediğinde iletişim meydana gelir(Osgood ve diğerleri, 1957). İletişim gönderiler aracılığıyla kurulan sosyal etkileşim olarak tanımlanabilir (Gerbner, 1967 aktaran Mcquail ve Windahl, 1982, çev. Yumlu ,2005,s.17)

İletişimin insanoğlunun hayatında var olduğu andan itibaren hep önemli bir yeri olmuştur. Teknolojik gelişmeler ne kadar artarsa artsın, iletişim ihtiyacı azalmayacak, artacaktır. Dolayısı ile iletişim araçlarının artması insanın iletişim ihtiyacını azaltmamış, aksine artırmıştır. Çünkü insanoğlunun iletișim kurabileceği insanların sayısı ve iletişim kurabileceği teknik araçların sayısı sürekli artmaktadır.

\section{Siyasal İletişim ve Sosyal Medya İlişkisi}

İletişim biliminin önemli uygulama alanlarından biri de siyasal iletişim alanıdır. Politik halkla ilişkiler veya siyasal iletişim olarak literatürde adlandırılmaktadır.

"Siyasal iletişim özellikle bünyesinde reklamcılığa benzer bir işlevi barındırmaktadır. Reklamcılık bir ürünün satılmasına yardım ederken, malı satın alanın da yaptığı seçimin doğru olduğuna her gün yeniden inanması gerekmektedir. İnsanlar günlük yaşamlarında her gün bu tür meșruluk arayıșı içerisindedirler"(Yavaşgel, 1997, s.232). Siyasal iletişim kampanyalarında yapılan da bir nevi bir reklam filmindeki ürün, mal veya hizmetin satın alınmaya teşvik edilmesi ile birebir aynıdır. Ürün reklamlarında müşterilere A markasına ait olan ürünün özellikleri övülerek anlatılırken, reklam filminin sonunda "bu ürünü satın al" mesajı verilir. Siyasal iletişim kampanyalarında da buna benzer şekilde bir siyasi figür, aktör ya da siyasi partinin faaliyetleri aktarılır ve çalışmaların sonunda "şimdi seçimde A Partisi'ne veya A siyasi parti başkanına oy ver" mesajı seçmene aktarılır.

"Siyasal iletişim, demokrasiyle yakından ilgili bir kavramdır. Siyasal iletişim, genel oy hakkının kitlelere verilmesiyle başlamış, kitle iletişim teknolojisinin gelişmesiyle de günümüzdeki anlamına ulaşmıștır. Siyasal iletișim kavramı ve uygulaması, İkinci Dünya Savaşı sonrası Amerika Birleșik Devletleri'nde doğup gelişmiş, 1960'lı yıllarda da Batı Avrupa ülkelerinde yaygın bir şekilde kullanılmaya başlanmıştır"(Topuz, 1991 s.7). Siyasal 
iletişim ve demokrasi kavramı birbirinden ayrılmaz iki kavramdır. Zira demokrasinin en temel özelliklerinden biri halkın kendi idarecilerini kendi marifetiyle, seçimle oy vererek seçmesidir. Bu süreçte de hem halk siyasilere taleplerini aktarmak konusunda iletişim teknik ve araçlarından faydalanmaktadır hem de siyasiler halkın desteğini alıp iktidar olmak için iletişim teknik ve araçlarından istifade etmektedirler.

Siyasal iletişim kavramına genel bakış açısı getiren tanımlardan biri de şudur: "Bir siyasal görüş ya da organın, etkinlikte bulunduğu siyasal sistem içinde kamuoyu güvenini ve desteğini sağlamak, dolayısıyla iktidar olabilmek için, zaman ve konjonktürün gereklerine göre reklam, propaganda ve halkla ilişkiler tekniklerinden yararlanarak sürekli bir biçimde gerçekleştirdiği tek veya çift yönlü iletişim çabasıdır"(Uslu, 1996. s.790). Bilindiği üzere her siyasi oluşumun açıkça beyan etse de etmese de temel gayesi seçimlerde halkın teveccühünü almak ve iktidar olmaktır.

$\mathrm{Bu}$ yüzden siyasetçilerin dilinde şu şekilde bir söylem olagelmiştir "Kimse siyasete muhalefet olmak için girmez, herkes iktidar olmak ister". Siyasal aktörlerin halkın teveccühünü elde etmelerinin ve iktidar olmalarının yegâne yolu seçmenleri etkileyecek iletişim teknik ve araçlarını doğru şekilde kullanmaktan geçmektedir. Bu tanımlamada siyasal aktörlerin temel kaygısı olan "kamuoyu desteği sağlamak" konusuna vurgu yapılmaktadır. Aynı zamanda siyasal iletişim çalışmalarının kimi zaman tek yönlü yani siyasetçiden veya siyasal partiden seçmene doğru kimi zaman ise siyasal organizasyon veya kişiden seçmene mesaj gönderimi ve seçmenin görüşlerinin de siyasetçi veya siyasal partiye aktarıldı̆̆ı iki yönlü bir iletişim çabası halinde gerçekleştiğine vurgu yapılmaktadır.

"Siyasal iletişim kimileri için siyasetçilerin sözlerinin medyadan aktarılması, kimileri için siyasal konular üzerine tartışma ve habercilik, kimileri içinse tüm siyasal süreçleri, iletişim biçimlerini içeren daha geniş ve kapsayıcı bir kavramdır"(İnal, 1999, s.3). Bu tanım da bizlere siyasal iletişim kavramının ne kadar genişletilebileceğine ilişkin bir çerçeve sunmaktadır. Tek yönlü bir mesaj aktarımından başlayıp bütüncül bir siyasal kampanyanın tamamını kapsayacak şekilde siyasal iletişim kavramı genişletilebilir.

"Demokrasiler, vatandaşlarla siyasi adaylar arasında kurulan bir diyalogdur. Seçim kampanyaları ise bu diyalogun en bariz ve en sesli kısmını oluştururlar. Renkli ve büyük bir çekişmeye sahne olan kampanyalar vasitasıyla adaylar; seçmenleri, kendilerine oy vermeleri ve davalarını desteklemeleri için ikna etmeye çalışmaktadırlar"(Richard ve Pomper, 2002, s.47). Elbette siyasal iletişim denildiğinde doğal olarak yukarıdaki tanımda verildiği gibi seçim süreçlerinde gerçekleştirilen kampanyalar hemen akla gelebilir. Ancak unutulmamalıdır ki siyasal iletişim sadece seçim süreçlerinde yapılıp sonrasında bırakılacak bir uygulama değildir. Bir seçim döneminin bitmesi ile beraber hemen seçmenle tekrar iletişim kurmaya yönelik yeni faaliyetlere başlanabilir.

Siyasal halkla ilişkiler faaliyetlerini Brian McNair "Siyasal İletişime Giriş" adlı kitabında dört başlık altında tartışmıştır:

1. İlk olarak siyasal halkla ilişkileri "medya yönetimi" şeklinde ele alabiliriz ki bu durumda modern medyanın ihtiyaç ve taleplerini karşılamak üzere politikacıların serbest medyaya erişim ve medyada görünürlüklerini artırmaya yönelik faaliyetleri kast ediyoruz.

2. İkinci tartışma konusu olarak siyasal halkla ilişkilerde "imaj yönetimi” konusunu ele alabiliriz. İmaj yönetiminden kast edilen bireysel olarak politikacının imajı ve bunun 
örgütsel hedeflere uyacak şekilde nasıl şekillenebileceği ve ikinci olarak da siyasal organizasyonun imajını kast ediyoruz.

3. Bir diğer önemli tartışma konusu diğer faaliyetlerin başarılı olabilmesi için "siyasal organizasyonun iç iletişimidir".

4. Son olarak tartışılması gereken konulardan biri de "bilgi yönetimi faaliyetleridir"(McNair, 2011, s.121-124).

McNair'in bu tasnifi siyasal iletişim ve siyasal halkla ilişkilerin çok geniş bir disiplin olduğunu göstermektedir. Siyasal iletişim denildiğinde medya yönetiminden, imaj yönetimine, siyasal organizasyonun iç iletişiminden, bilgi ve belge yönetimine kadar çok geniş bir alanı kapsayan bir faaliyet olduğunu hatırlatmaktadır.

Zira bir siyasal organizasyon veya siyasal aktörün başarılı olabilmesi için yukarıda sayılan dört başlıkta da başarılı olması büyük önem arz etmektedir.

Siyasal iletişim konusunda bu girişten sonra sosyal medya ve siyaset bağına değinmek konunun bütünselliği açısından faydalı olacaktır.

"Sosyal medya kavramının ilk kısmı, yani sosyal, insanın diğer insanlarla iletişim kurma ihtiyacını, içgüdüsünü belirtmektedir. İlk insanlardan beri o veya bu şekilde birbirimizle iletişime geçiyoruz. Bizim gibi düșünen; yanlarında evimizde gibi rahat hissedebileceğimiz; düşüncelerimizi, duygularımızı, tecrübelerimizi, rahatça paylaşabileceğimiz insanların bulunduğu bir gruba dâhil olmak insani bir ihtiyaçtır. Medya ise bu insanlarla iletişime geçme yöntemlerimizdir. Bu iletişim davulla, çanla, yazıyla, telgrafla, telefonla, radyoyla, televizyonla, e postayla, web siteleriyle, fotoğrafla, ses dosyasıyla, videoyla, cep telefonuyla, kısa mesajla kurulabilir. Medya bu iletişimi sağlamak için kullandığımız teknolojilerin tümüdür"(Safko, 2010, s.4).

Safko ve Brake sosyal medya kavramını: "Medya etkileşiminde kullanılan fikirleri, bilgileri ve haberleri seçen insan toplulukları arasındaki faaliyetler, uygulamalar ve davranışlar olarak ifade etmektedir. Medya etkileşimleri, kelime, resim, video ve ses formunda kolayca ulaşım sağlamanın mümkün olduğu web tabanlı uygulamalardır" diye tanımlamışlardır(Safko ve Brake, 2009, s.6). Bu tanımda Safko ve Blake sosyal medyayı geleneksel medyadan ayıran önemli bir fakötüre vurgu yapıyorlar. Geleneksel medyada haberleri seçip ayıklayan eşik bekçileri yani editörler, yazı işleri sorumluları vb. kişiler varken sosyal medyada ise bu görevi bizzat sosyal medya platformlarını kullanan insanlar gerçekleşmektedirler. Örneğin hangi konunun Twitter gündeminde TrendTopic olacağını Twitter değil, Twitter aracını kullanan insanlar yani bu platformun kullanıcıları belirlemektedir.

Safko ve Brake kitaplarında sosyal medya araçlarını dört ana grupta incelemişlerdir (Safko ve Brake, 2009, s.45): 1. İletişim (communication) amacı ile oluşturulan 2. İşbirliği için 3. Eğitim ve öğretim için 4. Eğlence için

Çalışmada yer verilen sosyal medya araçlarının bazılarının sadece isimlerinin yazılmasını yeterli buluyoruz. Seçtiğimiz bazı sosyal medya araçları şunlardır: Bloglar, Mikrobloglar, sosyal ağlar, video paylaşım siteleri, fotoğraf paylaşım siteleri, iş ağları, doküman paylaşımı, müzik paylaşımı, bilgi paylaşımı, kişilerarası iletişim.

Siyasal iletişimde en önemli konulardan biri de hedef kitleye ulaşma işidir. Demokratik sistemlerde iktidar olmanın anahtarı hedef kitlenin beğenisini kazanabilmekten 
geçmektedir. Hedef kitlenin bir siyasi kişiliği veya oluşumu desteklemesi için demokratik ortamlarda siyasi aktör veya oluşumların vaatlerini ve söylemlerini duyması, görmesi ve bunları onaylaması gerekmektedir. İște burada devreye iletişim boyutu girmektedir. Siyasi partiler ve oluşumlar sürekli mesajlarını hedef kitlelerine ulaştırmak için çaba sarf etmişlerdir. Bunun için yazılı ve işitsel medyadan faydalanmışlardır. Gazetelere ilan vermek, televizyonlara tanıtım filmleri çekmek veya reklam vermek, televizyon programlarına ya da hedef kitlenin tercih ettiği radyolarda programlara katılmak ve radyo spotları ile tanıtım yapmak yoluna gitmişlerdir.

Siyasal iletişim ve sosyal medya bağına ilişkin gerek Türkiye gerekse dünya çapında birçok araştırma çalışması yapılmıştır. Bu çalışmaların bazılarını burada paylaşmanın konu bütünlüğü açısından önemli olduğunu düşünüyoruz.

Günümüzde geleneksel kitle iletişim araçlarının yanına sosyal medya araçlarının da siyasetçiler tarafından sıklıkla kullanıldığını görmekteyiz. Bunun en iyi göstergelerinden biri ABD başkanlık seçimi ve başkan Obama'nın kampanyasında sosyal medya kullanımıdır. Birçok otorite tarafından Obama'nın başarısında siyasal iletişim kampanyasında sosyal medya kullanımının etkili olduğu iddia edilmiștir. Bunun için bu konuda yapılmış akademik çalışmalara bakılabilir. Colin Delany tarafından hazırlanan "Learning from Obama" adlı çalışmadan etraflıca fikir alınabilir(Delany, 2009).

Siyasetin sosyal medya ile olan ilişkisine bakacak olursak üç önemli gelişme göze çarpmaktadır. Birincisi Obama'nın sosyal medya odaklı "Medya Gösterisi”, ikincisi Ortadoğu'da etkili olan "Arap Baharı", üçüncüsü ise ülkemizde yakın zamanda yaşanan “Gezi Olayları”dır. Amerika Başkanlık Seçimleri'ne bakıldığında General Eisenhower'ın radyoyu kullanarak seçim kazanmış ilk başkan olduğu, John F. Kennedy'nin ise televizyonu kullanarak başkanlık seçimlerini kazanan ilk başkan olduğu bilinir. Barack Obama'nın ise dijital teknolojileri kullanarak ve interneti arkasına alarak özellikle sanal sosyal ağları adeta fethedercesine seçim stratejisi oluşturması, ona internet ortamı aracılığıyla seçim kazanmış ilk başkan olma sıfatını kazandırmaktadır (Akıncı Vural ve Bat, 2009, 2758). 2008 ABD başkanlık seçimlerine kadar siyasiler en güçlü iletişim aracı olarak geleneksel medyayı görmüşlerdir. Televizyonlar, gazeteler, radyolar ve diğer araçlarıyla geleneksel medya siyasilerin seçmenlere ulaşmasında alternatifsiz konumunu korumuştur. 2008 yılında ABD'de yapılan başkanlık seçimleriyle birlikte sosyal medya siyasetin gündemine hızlı bir giriş yapmıştır. Sosyal medyanın ABD başkanlık seçimlerinde Obama tarafından başarıyla kullanılması, Avrupa'da yapılan seçimlerde benzer örnekleri ve başarı hikayelerini de beraberinde getirmiştir(Bostancl, 2014, s.86)

Siyasal iletişimde sosyal medya kullanımı konusunda literatürdeki önemli çalışma Alman Siyasi Partilerinin Facebook, Twitter, Flickr, Youtube gibi ortamlarındaki varlığını analiz eden, aynı zamanda konu ile ilgili bir saha araştırmasının da gerçekleştirildiği "Siyasal İletişimde Sosyal Medya Kullanımı" adlı çalışmadır. Bu çalışmayı Stefan Stieglitz, Tobias Brockmann ve Linh Dang Xuan 2012 yılında gerçekleștirmişlerdir (Stieglitz ve diğerleri, 2012, s.1).

"Dijital dünya çağında sosyal medyanın toplumdaki kamusal alan ve iletişim üzerinde etkisi olduğu söylenmektedir. Özellikle sosyal medya politik bağlamda yoğun olarak kullanılmaktadır. Facebook ve Twitter gibi popüler sosyal ağ sitelerinin siyasal katılımı arttırma potansiyeline sahip olduğuna inanılıyor. Bununla birlikte mikroblog sitesi Twitter, siyasi kurum ve organizasyonların yalnızca genel bilgileri değil aynı zamanda siyasi görüşlerini de kamuya duyurmaları için ideal bir platformdur. Siyasi kurumlar, 
politikacılar, politik vakıflar vb. Facebook sayfalarını veya topluluk gruplarını vatandaşlar ile doğrudan diyaloglara girmek amacıyla ve politik tartışmaları daha fazla teşvik etmek amacıyla kullanmaya başlamıştır"(Meti, 2014).

Sosyal medyanın siyasal iletişimde yoğun şekilde kullanılmasının en önemli gerekçelerinden biri de geleneksel medyada bulunmayan geri bildirim döngüsü ve interaktifliktir diyebiliriz. Geleneksel mecralarda (tv, gazete, radyo, dergi vb.) seçmenlere mesaj veren siyasetçiler, mesajlarının seçmen tarafından istedikleri doğrultuda algılanıp algılanmadığını hızlı bir şekilde görme imkânına sahip değillerdi. Kamuoyu araştırmaları yaptırmak sureti ile verdikleri mesajların seçmen üzerindeki etkisini mümkün olduğunca analiz etmeye çalışıyorlardı. Ancak bu hem güvenilirlik açısından bazı sakıncalar barındırıyordu hem de son derece maliyetli idi. Oysa sosyal medya araçları sayesinde siyasal aktörler seçmenlere vermiş oldukları mesajların geri bildirimini çok hızlı bir şekilde, daha güvenilir ve çok düşük maliyetle nerede ise sıfır maliyetle alabiliyorlar. Bir siyasi organizasyon veya siyasi bir aktör herhangi bir sosyal medya aracından örneğin Facebook veya Twitter'dan paylaştığı bir tanıtım filmine gelen yorumlar üzerinden filmin mesajını iletebilmiş mi, etkili olmuş mu, insanlar ne düşünüyor şeklindeki sorularına hızlı bir şekilde cevap bulabilmektedir.

Sosyal medyanın politik hayata etkileri konusunda yapılmış "Sosyal Medya ve Politikaya Etkisi” konulu çalışmada sosyal medyanın şu etkilerine vurgu yapılmıştır(Lakkysetty ve diğerleri, 2018, s.2110):

- Trend haber oluşturma

- Anketlere etki

- Politikacılarla doğrudan iletişim

- Demografi ve hedef kitleye erişim

- Söylentiler, sahte haberler ve komplolar

- Doğrulama sapması

Sosyal medyada siyasetçilerin atmış oldukları bir tweetle bir anda Türkiye veya dünyada trend topic (en çok bahsedilen konu) olabildiklerini görüyoruz. Aynı zamanda seçmenlerin siyasetçilerin açmış oldukları sosyal medya hesapları üzerinden politikacılara direkt mesaj yollama veya Twitter üzerinden politikacılara destek veya karşıt görüş bildirme imkânlarına ulaştıklarını görüyoruz. Sosyal medyanın seçmenler açısından faydaları olmakla beraber diğer taraftan yalan haberlerin yayılması veya gerçek olmayan komplo teorisi veya şehir efsanesi şeklindeki bir haberin gerçekmiş gibi sunulması hadiselerine de rastlamaktayız. Bu konuda en yakın örneklerden biri Gezi Parkı olayları esnasında yayılan gerçek olmayan haberler ve bu haberlerin kamuoyundaki etkisinde görülebilir(Konu hakkında yapılmış bir habere ilgili linkten ulaşılabilir: www.sabah.com. tr/gundem/2013/06/02).

"Sosyal medya, bireylerin bilgi, deneyim, görüş ve fikirleri birbirleriyle paylaşmalarını sağlar. Siyasi sektörle ilgili olarak, sosyal medya vatandaşlar arasında katılım ve demokrasiyi mümkün kılabilir. 2008 ABD başkanlık seçim kampanyalarının gösterdiği gibi, sosyal ağ siteleri, mikroblog hizmetleri veya weblogları gibi sosyal medya platformları, siyasi aktörler tarafından bilgiyi seçmenlere yaymak, onlarla iletişim kurmak ve onlarla tartışmak için başarıyla kullanılabilir(Stieglitz ve diğerleri, 2012, s.1). Sosyal medya hem vatandaşlara hem de siyasi aktörlere siyasi görüşmelerde yer almak ve herhangi bir siyasi içeriği özel ya da halka açık olarak paylaşmak için bir platform sağlar"(Shami ve Ashfaq, 2018, s.140). Eskiden siyasetçilerle seçmen arasındaki bağ daha çok tek yönlü 
idi ve bunun için geleneksel mecralar olan televizyon, gazete, radyo kullanılıyordu. Ancak eskiden tek yönlü siyasetçiden seçmene olan bu bilgi akışı sosyal medya platformlarının hayatımıza girmesi ile birlikte artık iki yönlü olarak devam etmekte. Artık seçmen sadece bir bilgisayar ve bir sosyal medya platformu üyeliği ile siyasi konulardaki duygu düşüncelerini gerek siyasetçilere gerekse kendi arkadaşlarına veya platformun diğer kullanıcılarına rahatlıkla ulaştırabilmektedir.

"Sosyal medyanın 2014 Avrupa Parlamentosu seçimlerinde politikaya etkisi üzerine yapılan bir çalışmada varılan sonuçlardan biri şudur: 2014 Avrupa Parlamentosu seçimleri, $28 \mathrm{AB}$ ülkesinin tamamındaki seçim yarışının, yeni medya teknolojilerininözellikle sosyal paylaşım siteleri ve mikroblogların seçim kampanyalarının ayrılmaz bir parçası olduğu ilk örneklerden birini temsil ediyor. Sosyal medya yoluyla siyasal iletişimin, geleneksel olarak ulusal meseleler üzerine siyasi rekabetin genişletilmesini sağlamak yerine, Avrupa meseleleri ile ilgili bir söylemi yansıttığını ve AB kurumlarının ve politikalarının geleceği ve şekli konusundaki tartışmayı politikleștirdiğini göstermektedir" (Nulty ve diğerleri, 2016, s.34).

Köseoğlu ve Al tarafından hazırlanan "Bir Siyasal Propaganda Aracı Olarak Sosyal Medya" başlıklı çalışmada sosyal medyanın siyasal iletişime katkıları şu şekilde aktarılmıştır: Oysa sosyal medya kullanımı, maliyet açısından klasik propaganda yöntemlerine nazaran mukayese edilemeyecek oranda ucuz bir yöntem olarak görünmektedir (Wolfsfeldvd, 2013: s.3). Sosyal medyanın maliyetler hususunda ortaya koyduğu bu olumlu imkân, siyaseti ekonomik olarak birtakım kaygılardan arınmış ve gerek propaganda ve gerekse teşkilatlanma için yeteri kadar kaynağı aktarabilecek ya da temin edebilecek kişilerin tekelinde, elitist bir uğraş olmaktan çıkarmaktadır. Yakın tarihteki siyasi içerikli toplumsal hareketlerin başlatıcılarına bakıldığında (Salvatore, 2013; s.220-221), bu kişilerin sıradan vatandaşlar olduğu ve sosyal medya aracılığıyla yayınladıkları basit mesajlarla kitleleri rahatlıkla harekete geçirebildikleri görülmektedir. Bir siyasal propaganda aracı olarak sosyal medya kullanımının bir diğer avantajı ise diğer propaganda araçlarına nazaran daha geniş kitlelere ulaşılabilmesidir(Wolfsfeldvd, 2013: s.3 aktaran Köseoğlu ve Al, 2013, s.117) Görüldügü üzere sosyal mecralar siyasal iletişime maliyet alanında çok ciddi kolaylıklar sağlamaktadır. Normal şartlar altında geleneksel mecralarda çok daha büyük bütçeler gerektirecek maliyet kalemleri sosyal medya mecralarının birçoğunun ücretsiz olması marifeti ile ciddi oranda azalmaktadır. Ayrıca sosyal medya platformlarının hedef kitleye ulaşım oranında siyasal aktörlere çok büyük bir katkı sağladığı da unutulmamalıdır. Özellikle Türkiye gibi genç nüfusun ülke nüfusu içinde büyük bir oranı kapsadığı ülkelerde sosyal medyanın önemi daha da artmaktadır.

Akar "İnternetle Değişen Siyaset Pazarlaması: Dünyadan Örneklerle Yeni Trendler" adlı çalışmasında siyaset pazarlamasında kullanılan yeni eğilimleri şu şekilde açıklamıştır:

1. Web sitesi ve e-mail yoluyla siyaset pazarlaması

2. Siyasi blog ve siyasi blogging ile siyaset pazarlaması

3. Sosyal ağ ve video paylasım siteleri yoluyla siyaset pazarlaması (Akar, 2015, s.2

Sosyal medya mecralarının özellikle gençler tarafından tüm dünyada sıklıkla kullanılır olması, internete erişimin birçok ülkede geçmişe nazaran çok daha kolay ve maliyetinin az olması sebebi ile siyasetçiler seçmenin internet ve sosyal medya kullanımına kayıtsız kalmayıp siyasal iletişim stratejilerini doğal olarak internet ve sosyal medya mecralarına kaydırmaya başlamışlardır diyebiliriz. 
Sosyal medyayı siyasi partiler açısından değerlendirirken, internette yer alan diğer siyasal platformlardan ayrı tutmak gerekir. Çünkü Web 2.0'ın özelliklerinden beslenen sosyal mecralar, potansiyel seçmenin halihazırda yerleşik bulunduğu platformlar olarak partilerin stratejik kararlarına doğrudan tabi değildir. Diğer bir deyişle, siyasi partiler de tıpkı seçmenler gibi bu sosyal ağların birer üyesidir ve de bu mecraların yönetiminde sinırlı etkiye sahiptir. Bu noktada, kurumsal sosyal medya hesapları ile parti siteleri arasındaki ayrıma dikkat çekmek gerekir. Çünkü sosyal medyanın siyasal iletişim aracı olarak deneyimlenmesi, her ne kadar yukarıdan aşağıya bir ilişkiyi temsil ediyor gibi görünse dahi içinde farklı türden dinamikleri barındırmaktadır. Söz konusu dinamiklerin temel belirleyicisi ise, siyasi aktörlerin seçmene, yani yurttaşa yakınlaşmasını sağlayan etkileşim unsurudur(Bayraktutan ve diğerleri, 2014, s.62). Sosyal medya platformlarının yapısından kaynaklanan bu durum gerçekten önemli bir ayrıma işaret etmektedir. Zira bir siyasi parti web sitesinde içeriği tamamen kendisi yönetmektedir. Web sitesinde istediği haberleri alırken istemediklerini dışarıda bırakmaktadır. Ayrıca web sitesini ziyaret edenlerin site içeriğine müdahalesi web site yöneticisinin izin verdiği kadardır. Sosyal medya platformlarında siyasi partilerin hesaplarında örneğin Facebook veya Twitter gibi platformlarda diğer kullanıcılar siyasi partilerin veya aktörlerin hesaplarındaki paylaşımlara yorum yapabilmektedir. İçeriği hızlı bir şekilde başkaları ile paylaşabilmektedirler. Örneğin Twitter platformunda bir siyasi partinin yaptığı paylaşım çok takipçisi olan bir kişi tarafından retweet edilmek sureti ile başka kişilere onların retweetlemesi ile de binlerce kişiye ulaşabilmektedir. Bu özellik sosyal medya platformlarını geleneksel internet mecralarından ayırmaktadırlar.

Rune Karlsen ve Bernard Enjolras Norveç’te gerçekleştirmiş oldukları çalışmada şu sonuçlara ulaştıklarını ifade etmişlerdir: "Sosyal medya siyasi adaylardaki güç ilişkilerini etkileme potansiyeline sahip olduğundan, bireysel adayların merkezi partiden bağımsız olarak kampanya yapmasına olanak tanır. Bu çalışmada 2013 Norveç adayı anketini adaylarla birleştiren bir çalışmada bireyselleşme ve dijital sosyal medya arasındaki ilişkiyi inceliyoruz. Çalışma kapsamında iki ana sosyal medya kampanyası türü bulduk: Parti merkezli ve kişiselleștirilmiş"(Karlsen ve Enjolras, 2016, s.1). Bu çalışmada vurgu yapılan kişiselleştirilmiş yani partiden bağımsız olarak siyasal aktörlerin seçim kampanyası yürütmesine imkân vermesi açısından sosyal medya araçları önemli bir kurtarıcı görevi üstlenmişlerdir. Zira bir seçim esnasında siyasal kampanya gerçekleştirmek çok ciddi bir bütçe gerektirmektedir. Kampanya için çalışacak iletişim ekibindekilerin ücretleri, geleneksel medyada reklamları için ayrılacak bütçe (televizyon, gazete, radyo vb. reklam ücretleri) bunun yanında seçim öncesi gerçekleştirilecek saha araştırmaları bütçesi derken seçim kampanyaları bir kişinin tek başına gerçekleştirebileceği bütçelerin çok üstünde bir tanıtım kampanyası haline dönmektedir. Bu sebeple ülkemizde de yardım almaya hak kazanan siyasi partilere devlet tarafından seçim bütçesi verilmektedir. Türkiye'de bu yardım milletvekili genel seçimlerinde \% 7 barajını aşan partilere yapılmaktadır. Bu konuda dönemin Maliye Bakanı Mehmet Şimşek 2015 yılı için siyasi partilere toplamda 531 milyon TL ödenek verileceğini duyurmuştur. Buna göre Ak Parti 298 Milyon TL hazine yardımı alırken, CHP 115,3 milyon TL MHP ise 77,8 Milyon TL yardım almışlardır(www.haberturk.com/ekonomi/is-yasam/haber/1012962).

Bu hazine yardımları bize göstermektedir ki seçim kampanyaları siyasi partiler için büyük iletişim ve tanıtım harcamaları olan etkinliklerdir. Zira seçimler için ciddi insan kaynağı ve çok büyük reklam ve tanıtım bütçeleri kullanılmaktadır. Böyle bir ortamda herhangi bir parti çatısı altında seçime girmeyen bağımsız bir siyasal aktörün bu seçimlerde rakipleri 
ile mücadele etmesi en azından iletişim ve tanıtım anlamında mümkün olmamaktadır. İşte bu noktada devreye sosyal medya girmektedir. Zira Facebook sayfası açarak, Twitter hesabı açarak veya Youtube kanalı üzerinden bir siyasetçi çok düşük maliyetlerle kendisini seçmenlerine duyurma ve mesajını onlara aktarma imkânı herkese eşit şekilde verilmiştir. Ancak bu imkânların varlığı sosyal medyayı tamamen ücretsiz ve para gerektirmeyen bir mecra olarak düşündürtmemeli. Zira sosyal medya kampanyalarına dijital iletişim çalışmalarına da ciddi bütçeler ayırmak gerekebilir. Bunun için 2012 yılı ABD başkanlık seçimlerine bakabiliriz. Forbes'un haberine göre 2012 yılında Obama ve rakibi Romney siyasal reklam faaliyetleri için toplamda yaklaşık 2 milyar dolar ayırmışlardır. Peki, bu harcamaların ne kadarı dijital iletişime ayrıldı diye soracak olursak, aynı haber kaynağına göre Obama 2008 Yılı'nda başkanlık yarışı için dijital mecralara reklam bütçesinin \%10’unu ayırmıştır ki bu oran da yaklaşık 8 Milyon dolara tekabül etmektedir. (https:// www.forbes.com/sites/realspin)

Ancak daha önce de değinildiği gibi tüm bu yüksek bütçelere rağmen unutulmaması gereken teorik olarak seçimlere bağımsız giren bir adayın tamamı ücretsiz olan Facebook, Twitter, Youtube gibi sosyal medya ortamlarında hesap açması ve kampanyasını buradan yürütmesi mümkündür. Geleneksel medyada siyasi parti adaylarının yanında yer bulamayan kişiler sosyal medyada kendisini tanıtma imkânına sahiptir. Bu da sosyal medyanın siyasal iletişime önemli bir katkısıdır denilebilir.

2015 yılında Konrad-Adenauer-Stiftung (KAS) tarafından düzenlenen konferanstan nihai görüş birliği olarak, sosyal medya platformlarının siyasal iletişim bağlamında geleneksel medyanın gözlemlenen sınırlamalarının çoğunun üstesinden gelmesine büyük katkı sağladığı çıktı. Özellikle, sosyal medyanın halkla serbest ve hızlı bir şekilde bilgi paylaşımı için ve vatandaşlara asgari işlem maliyetleriyle siyasi ve politika konularında geri bildirim almaları için kanallar sağladığı belirtildi. Böyle bir gelişme sadece politikacıların vatandaşlar ile iletişim kurmasına izin vermekle kalmıyor; sosyal medya aracılığıyla ifade edilen vatandaş görüşlerinin hükümet ve siyasi partilerdeki liderlerin aldığı kararları bilgilendirdiği, sosyal medyanın yine bu kararların iletildiği ve sürekli olarak tartışıldığı bir platform sağladığı beklentisi ile de desteklenmektedir(Kamp, 2016, s. 32). Sosyal medyanın siyasal iletişimdeki en önemli etkilerinden biri siyasî organizasyonlarla seçmenler arasındaki iletişimi tek yönlü monolog olmaktan ziyade çift yönlü diyalog haline taşımış olmasıdır denilebilir. Sosyal medya hayatımızda yokken seçmenlerin siyasetçilere ulaşması, herhangi bir konuda duygu ve düşüncelerini aktarması çok zor iken şimdi bir akıllı telefon ve internet bağlantınız varsa ulaşmak istediğiniz siyasî organizasyon veya kişinin kurumsal sosyal medya hesaplarından rahatlıkla ulaşabilirsiniz.

Sosyal medya araçları ve bu araçları kullanan seçmen eskilerde geleneksel medya kuruluşları için kullanılan dördüncü kuvvet deyiminin yerini almaya aday denilebilir. Zira herhangi bir siyasete ilişkin konu hakkında sosyal medya üzerinden başlatılan kampanyaların siyasilerin karar almalarında etkileri olduğunu unutmamak gerekir. Zira sosyal medya seçmenlerin, vatandaşların çok hızlı bir şekilde organize olabildikleri ve birbirlerini hızlı bir şekilde etkiledikleri bir mecra halini almıştır.

\section{Sosyal Medya Kullanımı İstatistikleri}

Çalıșmanın bu bölümünde sosyal medya kullanımına ilişkin istatistiklerle dünya genelinde ve Türkiye'de sosyal medya araçlarının hayatımızda ne kadar yer kapladığına ilişkin bilgiler paylaşılmıștır. 
Dünya genelinde dijital kullanım istatistikleri konusunda üretilen "Digital 2019" adlı raporda insanların internet teknolojileri kullanımına ilişkin şu veriler paylaşılmıştır: (wearesocial.com/digital-2019)

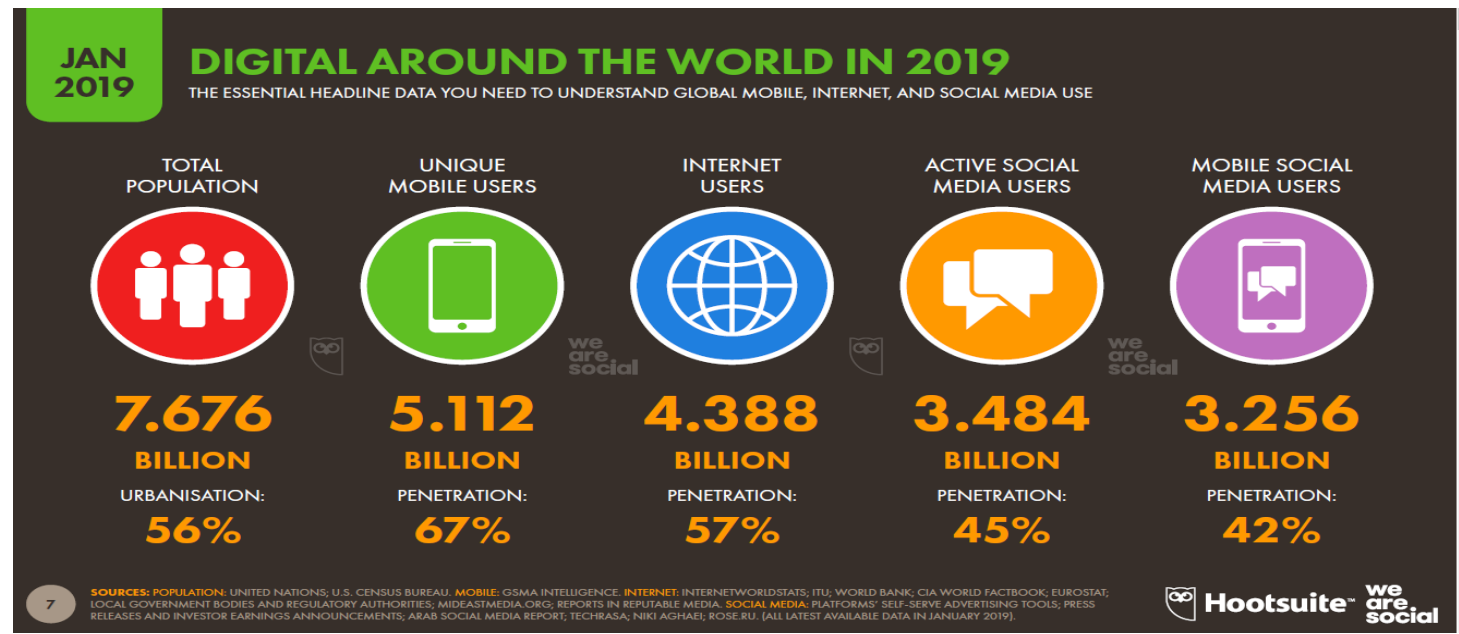

Görsel 1: Digital 2019 Raporu Dünyada Dijital Mecra Kullanımı Oranları

Araștırma verilerine göre 7.milyar 676 milyonluk toplam dünya nüfusunun 5 milyar 112 milyonluk bölümü tekil mobil teknoloji kullanıcısı konumundadır. Dünya nüfusunun \%57'si yani 4 milyar 388 milyonu internet kullanıcısıdır. Dünya nüfusunun \%45'i yani 3 milyar 484 milyonu aktif sosyal medya kullanıcısıdır.

Aynı araştırmaya göre dünya genelinde ortalama bir günde internette geçirilen vakit ortalama 6 saat 42 dakikadır. Dünya genelinde mobil internete bir günde ayrılan süre ise ortalama 3 saat 15 dakikadır. Araştırmaya göre insanlar bir ay içinde internette geçirdikleri vaktin \%92'sini online video izlemek için, \%58'ini internet üzerinden TV içeriği izlemek, \%30'u internetten oyun oynamak, \%23'ü diğer oyun oynayanların videolarını izlemek, \%16'sını ise e spor turnuvaları izlemek için kullanmışlardır. Araştırmaya göre mobil cihazlar üzerinden sosyal medya kullananların sayısı 3 milyar 256 milyondur. Dünya üzerinde sosyal medyayı en yoğun şekilde kullanan ülkelerin ilk üç sıralaması Katar, Dubai, Brunei Krallığı şeklinde sıralanmıştır.

Araștırmaya göre sosyal medya kullanımının yaş ve cinsiyetlere göre dağılımı aşağıdaki gibidir:

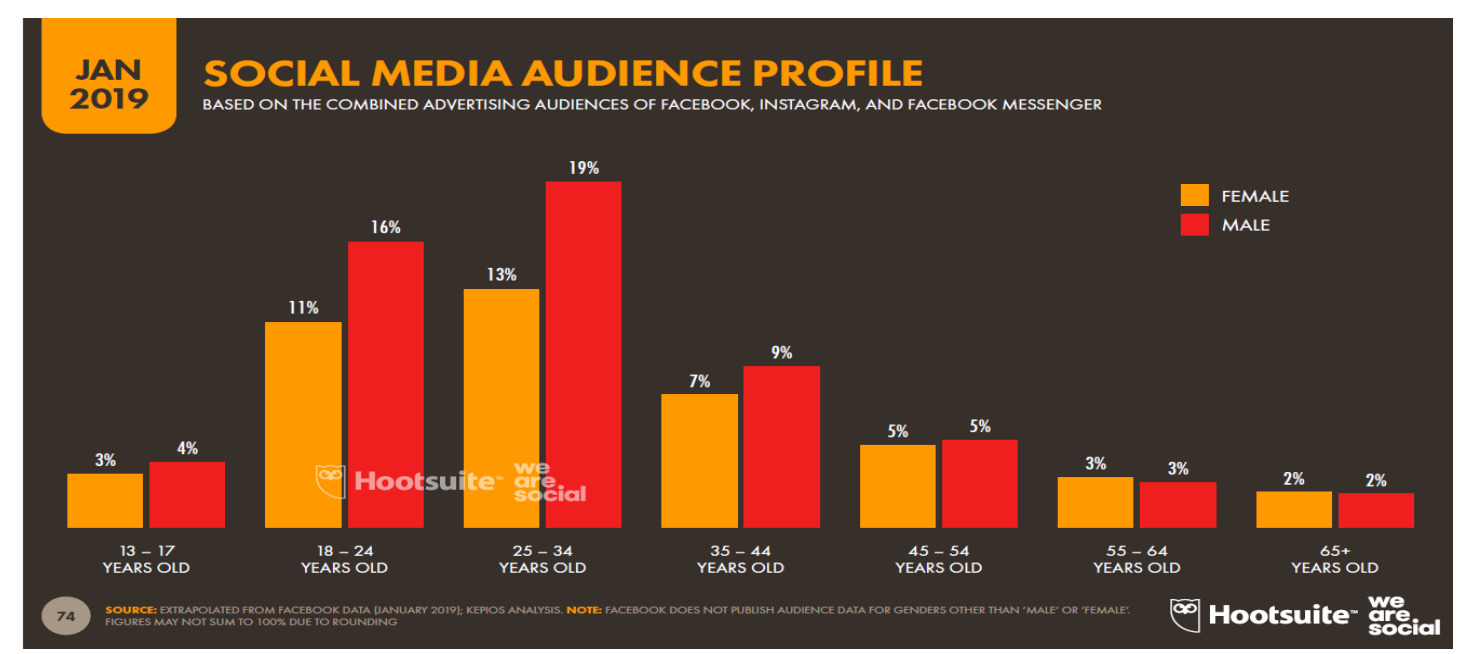

Görsel 2: Digital 2019 Raporu Sosyal Medya Kullanıcl Profillerinin Yaş ve Cinsiyete Göre Dağılımları 
$\mathrm{Bu}$ verilere göre sosyal medya mecralarının en yoğun şekilde 18-35 yaş aralığında kullanıldığı en az ise 55 yaş ve üzerinde kullanıldığı görülmektedir. Bu da sosyal medyanın özellikle gençler tarafından yoğun şekilde kullanıldığının bir göstergesidir. Araştırmaya göre dünya genelinde en çok kullanılan sosyal ağlar ve kullanıcı sayıları şu şekildedir: Facebook 2 milyar 271 milyon, Youtube 1 milyar 900 milyon, Instagram 1 milyar, TikTok 500 milyon, Twitter 326 milyon, Linkedin 303 milyon, Pinterest 250 milyon.

\section{Türkiye'de Gençlerin Sosyal Medya Kullanımı}

Türkiye'de gençlerin sosyal medya kullanımı konusunda yapılmış en kapsamlı çalışmalardan biri Gençlik ve Spor Bakanlığı tarafından "Gençlik ve Sosyal Medya Araștırma Raporu” başlığı ile 2014 yılında gerçekleștirilmiştir (https://leventeraslan. files.wordpress.com/2015/09/).

Araştırma kapsamında Temmuz-Eylül 2013 tarihleri arasında 26 ilde 2057 genç ile görüşülmüştür. Gençlerin yaş aralığı 15-29 yaş arası gençlerden oluşmaktadır. Araştırma sonuçlarına göre Türkiye'de gençlerin \%86'sı sosyal medyaya günde en az bir kere; \%72'si ise her gün birkaç kere bağlanmaktadır. Her üç gençten biri sosyal medyada günde en az 3 saat geçirmektedir.

Araştırmaya göre gençlerin sosyal medya kullanım şekillerine bakıldığında en çok "sosyal medyada listelerindeki kişi ve kurumların paylaştıklarını takip ettikleri"(\%89) ve “arkadaşlarının paylaştıklarına yorum yaptıkları"(\%88) görülmektedir. Sosyal medyada görsel yükleme, yazı yazma, tweet atma, ürün/marka/şirket hakkında yorum yazma gibi gençlerin kendi oluşturduğu içeriği başkalarıyla paylaşma davranışlarıyla yoğun bir şekilde karşılaşılmıştır. Sosyal medya mecraları arasında Facebook, internet kullanıcısı 15-29 yaş grubunun en çok kullandığı sosyal medyadır(\%89). Facebook'u ikinci sırada Youtube ve Instagram gibi görsel paylaşım siteleri takip etmektedir(\%57). Sosyal medya mecraları arasında Twitter'da popüler bir mecradır. Çalışmaya katılan 15-29 yaş grubundaki gençlerin \%45'i Twitter kullanıcısıdır. Gençlerin yarısı (\%50) sosyal medyada tartışmaya/polemiğe en az bir kere girmiştir. 15-17 yaş grubu erkekler, öğrenciler ve bekârlarda bu oran daha yüksektir. Gençler sosyal medyayı en çok eğlence (\%60) ve bilgi alma/sağlama (\%59) amacıyla kullanmaktadır. Gençlerin sosyal medyada en çok yorum yaptığı ilk üç konu günlük olay ve durumlar (\%60), müzik-film-TV-dizi yorumları (\%55) ile toplumsal konu ve olaylardır(\%43). Erkeklerde ilk iki sırayı spor(\%47) ve teknoloji(\%46) takip ederken, kadınlarda moda ve alışveriș(\%51) olarak belirlenmiştir(Gençlik ve Sosyal Medya Araştırma Raporu, s.17).

Türkiye'de gençlerin sosyal medya kullanımları ile ilgili yapılan bazı akademik araştırma sonuçlarına yer vermek istiyoruz. İlk olarak Solmaz ve diğerleri tarafından Selçuk Üniversitesi İletişim Fakültesi öğrencileri üzerinde gerçekleștirilen "İnternet ve Sosyal Medya Kullanımı Üzerine Bir Uygulama” konulu araştırma sonuçlarından bazılarını paylaşmak istiyoruz. 500 öğrencinin katıldığı araştırmada gençlerin sosyal medya kullanım düzeyi \%97,6 çıkmıştır. En çok tercih edilen sosyal ağ \% 79 ile Facebook olmuştur. Gençler sosyal medyadaki içeriklere \% 72,2 oranında yorum yaptıklarını ifade etmişlerdir. Gençlerin sosyal medyayı kişi ve organizasyonlara ulaşmak için kullanma oranları \%66 oranında çıkmıştır(Solmaz ve diğerleri, 2013, s. 26-30).

Gülcan ve diğerleri tarafından gerçekleştirilen "Meslek Yüksekokulu Öğrencileri ve Sosyal Ağlar: Nazilli, Atça ve Kuyucak Meslek Yüksekokullarının Karşılaştırılması” adlı çalışmada üniversitede okuyan meslek yüksekokulu öğrencilerinin sosyal medya kullanımına 
ilişkin şu istatistiklere ulaşılmıştır: Araştırmaya katılan öğrencilerin \%98'i Facebook, Twitter gibi sosyal ağ sitelerinden herhangi birini kullanmaktadır. Öğrencilerin \%83,7'si sosyal ağları her gün, \%12,3'ü haftada birkaç defa, \%1,7'si ayda birkaç defa kullandığını belirtmiştir(Gülcan ve diğerleri, 2015, s.166).

Üksel tarafından hazırlanan "Kullanımlar ve Doyumlar Kuramı Çerçevesinde Sosyal Medya Kullanımı: Sakarya Üniversitesi Öğrencileri Üzerine Bir Araştırma” adlı yüksek lisans çalışmasında öğrencilerin sosyal medya kullanım alışkanlıklarına ilişkin şu istatistiklere ulaşılmıştır: Katılımcıların haftalık sosyal medya kullanma sıklıklarına bakıldığında ise yüzde 5.5'inin haftada 1-2 gün, yüzde 11.3'ünün haftada 3-4 gün, yüzde17.3'ünün haftada 5-6 gün ve yüzde 66.0'sının da her gün düzenli kullandığı görülmektedir. Ortaya çıkan bu sonuçlar katılımcıların çoğunluğunun (yüzde 66.0'sının) her gün düzenli olarak sosyal medyayı kullandıklarına işaret etmektedir(Üksel, 2015, s.96).

Ali Murat Kırık tarafından hazırlanan "Yeni Medya Çağı Çerçevesinde Türkiye'de Televizyondan İnternete Dönüşüm ve Sosyal Paylaşım Ağlarında Gençlerin Konumu” başlıklı doktora tezinde ulaşılan verilere göre; Katılımcıların hemen hemen hepsinin (1003 kişi) Facebook üyesi olduğu görülmüștür. Twitter'da profili olan katılımcıların sayısı da azımsanacak ölçüde değildir. Katılımcılara göre en popüler sosyal paylaşım ağları Facebook ve Twitter olmuştur. Facebook ve Twitter'ı, Google+, YouTube, Linkedin ve MySpace takip etmiştir. Katılımcıların hemen hemen hepsinin kişisel bilgisayarı bulunmaktadır(Kırık, 2013, 337).

Küçükali tarafından Atatürk Üniversitesi öğrencileri üzerinde gerçekleștirilen "Üniversite Öğrencilerinin Sosyal Medya Kullanımı: Atatürk Üniversitesi Örneği” adlı çalışmada öğrencilerin sosyal medya kullanımı irdelenirken sosyal medyada siyasal mesajlara tepkileri de sorulmuştur. Yapılan değerlendirme sonuçları şu şekildedir. Tablo 4'ün verileri içerisinde en düşük kabul edilen düşünceler şunlardır:

- Sosyal medyayı siyasi ve ideolojik düşüncelerimi belirtmek için kullanırım,

- Sosyal medyayı insanları daha iyi tanımak ve yeni dostluklar edinmek için kullanırım

- Sosyal medya, gündelik hayatımda tutum ve davranışlarımda bir değişiklik meydana getirmektedir.

- Öğrencilerin tamamına yakını ise "sosyal medyayı eğlenmek ve rahatlamak için kullanırım” düşüncesini onaylamış gözükmektedirler (Küçükali, 2016, s.543).

$\mathrm{Bu}$ araștırmadaki önemli bulgulardan biri, öğrencilerden "sosyal medyayı siyasi ve ideolojik düşüncelerimi belirtmek için kullanırım” diyenlerin oranının son derece düşük çıkmasıdır. Bunun yanında öğrenciler daha çok sosyal medyayı eğlenmek, hoş vakit geçirmek amaçlı kullandıklarını ifade etmişlerdir.

Literatür taraması esnasında görülmüştür ki siyasetçiler, siyaset teorisyenleri, bu konuda saha çalışmaları yapan insanlar sosyal medya kullanımının özellikle gençler üzerinde siyasal iletişim başarısında önemli bir etken olduğunu düşünmektedirler. Buradan yukarıdaki çalışma özelinde şu sonucu çıkarabiliriz: Öğrencilere ulaşmakta sosyal medya çok etkili bir araç olabilir ancak öğrenciler siyasete ilişkin duygu ve düşüncelerini sosyal medya platformlarında paylaşmadıklarını ifade etmişlerdir. Demek ki sosyal medyada siyaset konusunda gençler daha çok alıcı konumunda olup siyasal aktörlerden gelen mesajların izleyicisi konumunda kalıyorlar ancak kendi görüşlerini ifade etmekten çekiniyorlar. Bu soruna ilişkin bizim araştırmamızda elde edilen bulgular ilerleyen sayfalarda tartışılacaktır. 
Aydın tarafından Anadolu Üniversitesi öğrencileri üzerinde, 4332 kişinin katılımı ile gerçekleştirilen "Üniversite Öğrencilerinin Sosyal Medya Kullanımları Üzerine Bir Araştırma: Anadolu Üniversitesi Örneği” adlı araștırmada öğrencilerin interneti yoğunlukla sosyal medya araçları için kullandığına ilişkin şu sonuçlara ulaşılmıştır: Çalışmanın bulgularına bakıldığında katılımcıların internet kullanım sıklığının her gün beş altı saat aralığında yoğunlaştığı görülmektedir. Bu yoğunluk teknolojinin hızla ilerlemesiyle birlikte genç nüfusun daha erken bilgisayar ve internetle tanışmasıyla açıklanabilir. Bunun yanında araştırmada öğrencilerin internet kullanım sıkları ile sosyal ağ araçlarının kullanımı arasında da anlamlı bir ilişki bulunmuştur. Bu da gerek internetin gerekse sosyal ă̆ araçlarının üniversite öğrencilerinin hayatındaki yerini doğrudan göstermektedir(Aydın, 2016, s.382).

Literatür taramasında öğrencilerin internet kullanım amaçlarına bakıldığında başkaları ile iletişim kurmak, hoş vakit geçirmek, video izlemek, ödev araştırmak, gündemi takip etmek gibi amaçlardan bahsedilirken bu amaçların yanında sıklıkla sosyal medya platformlarında vakit geçirmek, sosyal medya platformlarında yeni arkadaşlıklar edinmek, sosyalleşmek gibi amaçların da söylendiği görülmüştür. Yukarıdaki araștırma da literatür çalışmalarındaki bulgularla örtüşmektedir. Bugün gençlerin internet kullanımında önemli amaçlardan biri de sosyal medya platformlarına erişim sağlamaktır.

Tüm bu sonuçlar göstermektedir ki, dünyadaki dijital dönüşüme paralel olarak Türkiye'de de özellikle gençler üzerinde internet ve sosyal medyanın ciddi bir etkisi vardır. Zira gençler günlük hayatlarının önemli bir bölümünü sosyal medyada geçirmektedirler. Türkiye'deki gençlerin sosyal medya mecralarını kullanma yoğunluk ve sıralamalarının da dünya geneli ile paralellik arz ettiği, Facebook'un en çok tercih edilen sosyal medya mecrası olduğu görülmüştür. Ardından da Youtube gibi video paylaşım platformları gelmektedir. Dünya geneli Digital 2019 araştırmasında da en çok kullanılan sosyal medya mecralarında video izleme kanalları üst sıralarda yer almakta idi. Dünya genelinde de insanların internet kullanma alışkanlıklarının önemli bir bölümünü video paylaşım sitelerinden video izlemek oluşturmaktadır.

\section{Saha Araştırması}

Araştırmamızın temel amacı, Düzce Üniversitesi Sosyal Bilimler Meslek Yüksekokulu öğrencilerinin sosyal medya kullanım alışkanlıklarını ölçümlemek ve öğrencilerin sosyal medya aracılığı ile yayılan siyasal mesajlara verdikleri tepkileri görmektir. Araştırmanın amaçlarını üç temel başlık altında toplayabiliriz:

- Düzce Üniversitesi Sosyal Bilimler Meslek Yüksekokulu öğrencilerinin internet kullanma alışkanlıklarını tespit etmek

- Öğrencilerin sosyal medya kullanım alışkanlıklarını belirlemek

- Öğrencilerin sosyal medyada siyasal içerikli mesajların yayınlamasına ve sosyal medyanın içinde siyasal iletişim faaliyetlerine ilişkin tutumlarını tespit etmek.

\section{Araştırma Metodolojisi}

Araştırma niceliksel araştırma tekniklerinden yüz yüze anket uygulama tekniği ile gerçekleştirilmiştir. Araştırma ölçeği oluşturulurken sosyal medya kullanımı konusunda daha önce gerçekleştirilmiş ve güvenilirliği sınanmış farklı akademik çalışmalardaki ölçeklerden istifade edilmiştir. Anket formunun ilk bölümünde gençlerin internette ne kadar vakit geçirdiklerini ölçen sorular sorulurken, ikinci bölümde hangi sosyal medya araçlarını ne yoğunlukla kullandığını ölçen sorular sorulmuştur. Üçüncü bölümde ise 
gençlerin sosyal medya platformlarında yayınlanan siyasal içerikli mesajlara ne şekilde tepki verdikleri ölçülmeye çalıșılmıştır. Sorularda 5'li likert ölçeği kullanılmıştır. Araştırmada örnekleme seçilen öğrencilere yönelik bir anket formu uygulanmıştır ve uygulanan bu anket formu SPSS programı kullanılarak analiz edilmiştir. Araştırmada demografi bilgileri dâhil 33 sorudan oluşan bir anket formu kullanılmıştır. Anketin uygulanacağı okulda 50 öğrenci ile pilot çalışma yapılmıștır. Pilot çalışmada görülen aksaklıklar nihai soru formuna geçilmeden düzeltilmiştir.

Anketin yapıldığı sırada evren olarak seçilen Düzce Üniversitesi Sosyal Bilimler Meslek Yüksekokulu'nun 1000 aktif öğrencisinin bulunduğu göz önüne alındığında \%5 hata payı ve \%98 güven seviyesinin elde edilmesi için 400 öğrenci ile anket yapılması gerekmektedir. Çalışmamızda toplam 422 geçerli anket yapılmıştır ve istenilen hata payı ve güven seviyesine ulaşılmıștır. Örnekleme dâhil olan öğrenciler gelişigüzel örnekleme tekniği ile seçilmiştir. Araştırmanın gerçekleştirildiği tarihte programlara ait sınıflara gidilerek o esnada derste olan öğrencilerle yüz yüze anket gerçekleştirilmiştir.

\section{Araştırmaya Katılanların Demografik Dağıımı}

Araștırmaya 182'si erkek 240’ı kız öğrenci olmak üzere toplam 422 öğrenci katılmıştır, katılımcıların \%43'ü erkek, \%57'si kadınlardan oluşmaktadır. Araştırmaya katılanların 124'ü İşletme (\%29), 133'ü Muhasebe (\%32), 165'i Sosyal Güvenlik (\%39) programı öğrencilerinden oluşmaktadır.

\section{Araştırmaya Katılanların Sosyal Medya Kullanım Alışkanlığı}

Tablo 1: Interneti Kullanma Amaçları

\begin{tabular}{|l|c|c|}
\hline İnterneti en çok hangi amaçla kullanıorsunuz? & Frekans & Yüzde \\
\hline Sosyal medya & 194 & 46,0 \\
\hline Araştırma & 82 & 19,4 \\
\hline İletişim (e posta, skype vb.) & 43 & 10,2 \\
\hline Ödev & 33 & 7,8 \\
\hline Haber & 29 & 6,9 \\
\hline Video & 12 & 2,8 \\
\hline Diğer & 11 & 2,6 \\
\hline Dosya indirme & 11 & 2,5 \\
\hline Cevap yok & 7 & 1,7 \\
\hline TOPLAM & 422 & 100,0 \\
\hline
\end{tabular}

Araştırmaya katılan öğrencilere interneti en çok hangi amaçla kullandıkları sorulmuştur. Öğrenciler \%46 oranı ile birinci sırada "sosyal medya" için kullandıklarını belirtirken, ikinci sırada \%19,4 ile "araștırma" amacı ile üçüncü sırada \%10,2 oranı ile posta vb. amaçlarla "iletişim" amacı ile interneti kullandıklarını belirtmişlerdir. Burada sosyal medyanın yüksek bir oranla ilk sırada çıkan internet kullanma amacı olması araştırma sonuçları açısından önemlidir.

Tablo 2: Internete Girme Sıklı̆̆

\begin{tabular}{|l|c|c|}
\hline Hangi sıklıkla internete giriyorsunuz? & Frekans & Yüzde \\
\hline Her gün & 220 & 52,1 \\
\hline Haftada 3 - 4 gün & 149 & 35,3 \\
\hline Ayda 1-2 gün & 46 & 10,9 \\
\hline 3 - 4 ayda 1 gün & 7 & 1,6 \\
\hline TOPLAM & 422 & 100,0 \\
\hline
\end{tabular}


Araştırmaya katılanların \% 52'si her gün internete girdiğini ifade etmişlerdir.

Tablo 3: En Fazla Vakit Geçirilen Sosyal Ağ

\begin{tabular}{|l|c|c|}
\hline Eğer birden fazla sosyal ağa üye iseniz en fazla hangisinde vakit geçiyorsunuz? & Frekans & Yüzde \\
\hline Facebook & 209 & 89,6 \\
\hline Twitter & 19 & 8,1 \\
\hline Blog & 2 & 0,8 \\
\hline Youtube & 2 & 0,8 \\
\hline Msn & 1 & 0,4 \\
\hline TOPLAM & 233 & 100 \\
\hline
\end{tabular}

Katılımcılar sosyal medya denildiğinde ilk akla gelen araçlardan biri olan Facebook'u $\%$ 89,6'lık bir yüzde ile ilk sırada belirtmişlerdir. İkinci sırada Twitter \%8,1 ile en çok kullanılan ikinci sosyal medya aracı olarak belirtilmiştir. Öğrencilerin açık ara en yoğun şekilde Facebook platformunu kullandıkları görülmüştür. Bu durum literatür kısmında paylaşılan diğer araştırma sonuçlarıyla paralellik arz etmektedir.

Tablo 4: Sosyal Ağları Kullanma Sıklığı

\begin{tabular}{|l|c|c|}
\hline Hangi sıklıkla sosyal ağları kullanıyorsunuz? & Frekans & Yüzde \\
\hline Her gün & 209 & 49,5 \\
\hline Haftada 3 - 4 gün & 140 & 33,2 \\
\hline Ayda 1-2 gün & 53 & 12,6 \\
\hline 3-4 ayda 1 gün & 20 & 4,7 \\
\hline TOPLAM & 422 & 100,0 \\
\hline
\end{tabular}

Araştırmaya katılan öğrencilerin yaklaşık \%50'si her gün mutlaka sosyal ağları kullandığını ifade etmişlerdir. $\mathrm{Bu}$ sonuç da gençlerin hayatında sosyal ağların yeri açısından önem arz etmektedir.

Tablo 5: Sosyal Ağları Kullanma Amaçları

\begin{tabular}{|l|c|c|}
\hline Sosyal ağları en çok hangi amaçla kullanıyorsunuz? & Frekans & Yüzde \\
\hline Zaman geçirmek & 243 & 57,6 \\
\hline Çevrimiçi sohbet etmek & 71 & 16,8 \\
\hline Fikirlerimi ifade etmek & 50 & 11,8 \\
\hline Diğer (Bilgilenmek, Oyun, haberleşmek, haber) & 25 & 5,9 \\
\hline Profilimi güncellemek & 13 & 3,1 \\
\hline Yeni arkadaş bulmak & 11 & 2,6 \\
\hline Cevap yok & 9 & 2,1 \\
\hline TOPLAM & 422 & 100,0 \\
\hline
\end{tabular}

Araştırmaya katılanların büyük bölümü sosyal ağları "zaman geçirmek" için kullandıklarını ifade etmişlerdir. "Fikirlerini ifade etmek" amacı ile kullanım oranı \%12'ler düzeyinde kalmıştır. Bu soru özelinde gençlerin sosyal ağları siyaset vb. konularda ya da gündeme ilişkin konularda fikirlerini ifade etmek için kullanmaması dikkatle irdelenmesi gereken bir konudur. Gençler sosyal medyayı yoğun şekilde kullanmaktadırlar. Ancak sosyal medyada fikirlerini ifade etmekten kaçınmaktadırlar. 
Tablo 6: Sosyal Ağlarda Siyasi Yorum Yapma Durumu

\begin{tabular}{|l|c|c|}
\hline Sosyal ağlarda siyasi konularla ilgili yorumlar veya paylaşımlar yapar mısınız? & Frekans & Yüzde \\
\hline Hayır yapmam & 284 & 67,3 \\
\hline Evet yaparım & 130 & 30,8 \\
\hline Cevap yok & 8 & 1,9 \\
\hline TOPLAM & 422 & 100,0 \\
\hline
\end{tabular}

Araştırmaya katılanların \%67,3'ü sosyal ağlarda siyasi konularla ilgili yorum veya paylaşım yapmadığını ifade etmiştir. Araştırmaya katılan gençlerin yaklaşık \%70’lik bir oranla çeşitli çekinceler sebebi ile internet ortamında siyasi görüş ifade etmekten kaçındığı görülmektedir.

Tablo 7: Siyasi Bir Görüşe Illişkin Sayfa Veya Kişi Takip Etme Durumu

\begin{tabular}{|l|c|c|}
\hline $\begin{array}{l}\text { Sosyal ağlarda herhangi bir siyasi görüşe ilişkin } \\
\text { sayfa veya kişiyi takip ediyor musunuz? }\end{array}$ & Frekans & Yüzde \\
\hline Hayır takip etmiyorum & 275 & 65,2 \\
\hline Evet takip ediyorum & 140 & 33,2 \\
\hline Cevap yok & 7 & 1,7 \\
\hline TOPLAM & 422 & 100,0 \\
\hline
\end{tabular}

Araștırmaya katılan gençlerin yaklașık \%66'sı sosyal ağlarda herhangi bir siyasi görüşe ilişkin sayfa veya kişiyi takip etmediğini ifade etmektedir. Bu da bizim açımızdan önemlidir. Siyasiler seçmene özellikle de genç seçmene ulaşmak için internet ortamını yoğun bir şekilde kullanırken etkilemek istediği kitle olan gençler ağırlıklı olarak siyasetçileri sosyal ağlardan takip etmediğini ifade etmiştir.

Tablo 8: Sosyal Medyayı Siyasi Düşünceleri İfade Etmek İçin Kullanma

\begin{tabular}{|l|c|c|}
\hline Sosyal medyayı siyasi düşüncelerinizi ifade etmek için kullanıyor musunuz? & Frekans & Yüzde \\
\hline Hayır kullanmıyorum & 349 & 82,7 \\
\hline Evet kullanıyorum & 68 & 16,1 \\
\hline Cevap yok & 5 & 1,1 \\
\hline TOPLAM & 422 & 100,0 \\
\hline
\end{tabular}

Araştırmaya katılan öğrencilerin yaklaşık \%83'ü sosyal medyayı siyasi düşüncelerini ifade etmek için kullanmadığını ifade etmektedir. Öğrencilerin niçin siyasal düşüncelerini ifade etmekten kaçındıkları konusunda da ayrıca çalışma yapılması fayda sağlayacaktır.

Tablo 9: Siyasal Tercihlerin Sosyal Medyadan Etkilenme Durumu

\begin{tabular}{|l|c|c|}
\hline Siyasal tercihlerinizi sosyal medyada yayınlanan içerikler etkiler mi? & Frekans & Yüzde \\
\hline Hayır etkilemez & 337 & 79,9 \\
\hline Evet etkiler & 77 & 18,2 \\
\hline Cevap yok & 8 & 1,9 \\
\hline TOPLAM & 422 & 100,0 \\
\hline
\end{tabular}

Araştırmaya katılan öğrencilerin yaklaşık \%80'i sosyal medyada yayınlanan içeriklerin siyasal tercihlerini etkilemediğini belirtmişlerdir. Bu da çarpıcı bir sonuçtur. Zira siyasal aktörler parti liderleri veya partiler özellikle genç seçmenleri etkilemek amacı ile sosyal ağları aktif bir şekilde kullanmakta ve partilerinin mesajlarını sosyal medya üzerinden vermektedirler. Ancak görmekteyiz ki araştırmaya katılan gençler sosyal medya üzerinden yayınlanan içeriklerden siyasal tercih bağlamında etkilenmemektedirler. 
Tablo 10: Siyasi Konuların En Çok Takip Edildiği Kaynak

\begin{tabular}{|l|c|c|}
\hline $\begin{array}{l}\text { Siyasi konulardaki güncel olayları ve tartışmaları en } \\
\text { çok hangi kaynaktan takip edersiniz? }\end{array}$ & Frekans & Yüzde \\
\hline Televizyon & 206 & 48,8 \\
\hline İnternet siteleri & 103 & 24,4 \\
\hline Gazete & 70 & 16,6 \\
\hline Sosyal ağlar & 29 & 6,9 \\
\hline Cevap yok & 7 & 1,7 \\
\hline Radyo & 5 & 1,2 \\
\hline Diğer & 2 & 0,5 \\
\hline TOPLAM & 422 & 100,0 \\
\hline
\end{tabular}

Araştırmaya katılan öğrencilerin yaklaşık \% 50’si siyasi konulardaki olayları geleneksel kitle iletişim araçlarından biri olan televizyondan izlediklerini ifade etmişlerdir. İkinci sırada internet siteleri gelirken, sosyal ağlar yaklașık \%7'lik bir oranla ancak dördüncü sırada gelmektedirler. Sosyal medyanın bir çı̆̆ gibi büyüdüğü günümüzde siyasî konularda hala geleneksel medya ve televizyonun birincil haber alma kaynağı olması önem arz etmektedir.

Tablo 11: Sosyal Ağların Öğrencilerin Fikirlerini Etkileme Durumu

\begin{tabular}{|l|c|c|}
\hline Sosyal ağlarda siyasal içerikli mesaj ve görüntüler fikirlerimi etkiler & Frekans & Yüzde \\
\hline Kesinlikle katılmıyorum & 143 & 33,9 \\
\hline Katılmıyorum & 125 & 29,6 \\
\hline Ne katılıyor ne katılmıyorum & 71 & 16,8 \\
\hline Katılıyorum & 51 & 12,1 \\
\hline Kesinlikle katılıorum & 32 & 7,5 \\
\hline TOPLAM & 422 & 100,0 \\
\hline
\end{tabular}

Araştırmaya katılan öğrencilere "Sosyal ağlarda siyasal içerikli mesaj ve görüntüler fikirlerimi etkiler" yargısına katılma düzeyi sorulmuștur. \%63,5'lik bir grup bu yargıya "kesinlikle katılmıyorum - katılmıyorum" cevabını verirken, \%19,6'lı bir grup ise "kesinlikle katılıyorum-katılıyorum" cevabını vermiştir. Öğrencilerin büyük bölümü sosyal ağlar üzerinden yayınlanan siyasal içerikli mesaj ve görüntülerin fikirlerini etkilemediğini beyan etmişlerdir.

Tablo 12: Sosyal Ağlarda Siyasal İçerikli Mesajları Silme Eğilimi

\begin{tabular}{|l|c|c|}
\hline Sosyal ağlarda siyasal içerikli mesajları dikkate almadan silerim & Frekans & Yüzde \\
\hline Kesinlikle katılmıyorum & 75 & 17,8 \\
\hline Katılmıyorum & 88 & 20,9 \\
\hline Ne katılıyor ne katılmıyorum & 115 & 27,3 \\
\hline Katılıyorum & 85 & 20,1 \\
\hline Kesinlikle katılıyorum & 59 & 14,0 \\
\hline TOPLAM & 422 & 100,0 \\
\hline
\end{tabular}

Öğrencilerin \%38,7'si "Kesinlikle katılmıyorum - katılmıyorum" cevabını verirken, \%34,1'i ise "Kesinlikle katılıyorum - katılıyorum" cevabını vermişlerdir. Bu da önemli bir sonuçtur. Öğrencilerin yaklaşık \%35'i sosyal ağlardaki siyasal içerikli mesajları okumadan sildiklerini ifade etmişlerdir. Bu da demektir ki siyasal içerikli mesajların yaklaşık 3'te 1'i okunmadan, hedef kitle tarafından görülmeden silinmektedir. 


\section{Sonuç ve Değerlendirme}

Araştırmamızda gençlerin interneti en çok \%46 oranı ile birinci sırada sosyal medya amacı ile kullandığı, ikinci sırada \%19,4 oranı ile araştırma amacı ile kullandığı, üçüncü sırada ise \%10,2 ile iletişim amacı ile kullandıkları tespit edilmiştir. Bu veriler bize internet kullanımında sosyal medyanın ne kadar önemli olduğunu göstermektedir. Bu sonuçlar Üksel tarafından gerçekleștirilen araştırma sonuçları ile paralellik arz etmektedir. Sakarya Üniversitesi öğrencileri üzerinde yapılan araştırmada öğrencilerin \%66'lık bir bölümü her gün sosyal medyayı kullandığını ifade etmiștir. Ayrıca Gülcan ve diğerleri tarafından gerçekleştirilen araştırmada da öğrencilerin \%83,7'sinin sosyal ağları her gün kullandıkları sonucuna ulaşılmıştır(Gülcan ve diğerleri, 2015, s. 166). Araştırmamızda da gençlerin interneti en yoğun sosyal medya platformları için kullandığı sonucuna varılmıştır. Bu sonuçlar sosyal medya platformlarının gençlerin internet kullanımında önemli bir yeri bulunduğunu göstermesi açısından önemlidir.

Araştırmaya katılanların sosyal ağları en çok hangi amaçla kullandıkları sorulduğunda \%57,6 ile "zaman geçirmek" birinci sırada yer alırken, \%16,8 ile "çevrimiçi sohbet etmek", \%11,8 ile "fikirlerimi ifade etmek" şeklinde sıralama ortaya çıkmıştır. Fikirlerini ifade etmek için kullanmanın üçüncü sırada çıkması sosyal medyanın bir fikir beyan etme yerinden daha çok eğlenmek, hoş vakit geçirmek için kullanıldığını göstermiştir. Araştırmaya katılan gençlerin en çok zaman geçirmek maksadı ile sosyal ağları kullandıkları sonucu da literatürde gençlerin sosyal medya kullanımı hakkında yapılan araştırma sonuçları ile paralellik arz etmektedir.

Araştırmaya katılan öğrencilerin \%55,5'i sosyal medyada yer alan içeriklere yorum yazmadıklarını belirtmişlerdir. $\mathrm{Bu}$ da araştırmaya katılan öğrencilerin daha çok takipçi rolünü üstlendiklerini her iki kişiden birinin yorum yazmaktan çekindiğini göstermektedir. Araștırmamızda sosyal medyada yer alan içeriklere yorum yazama davranıșı sonuçları Solmaz ve diğerleri tarafından yapılan araştırma sonuçlarından farklılık arz etmektedir. Solmaz tarafından gerçekleştirilen çalışmada gençlerin \% 72,2 oranında sosyal medyadaki içeriklere yorum yaptıkları ifade edilmiştir(Solmaz ve diğerleri, 2013, s. 26-30). Biz buradaki farklılığın şuradan kaynaklanabileceğini düşünüyoruz: Bizim araștırmamız doğrudan sosyal medyadaki siyasal içeriklerle ilgili olduğu için Solmaz'ın araştırmasında ise siyasal içerikler üzerinden soru sorulmadığı için gençlerin sosyal medya içeriklerine yorum yapma düzeylerinde farklılık oluşmakta olabilir. Elbette bunun sebepleri detaylı bir araştırma ile öğrenilmelidir.

Araștırmaya katılan öğrencilerin \%67,3'ü sosyal ağlarda siyasi konularla ilgili yorum yazmadıklarını beyan etmiştir. Yani öğrencilerin siyasi konulara ilişkin görüşlerini paylaşmada çekimser davrandıkları sonucuna ulaşılmıştır.

Araștırmaya katılan öğrencilerin \%65,2'si sosyal ağlarda herhangi bir siyasi görüșe ilişkin kişi veya sayfayı takip etmediğini belirtmiștir. Bu da öğrencilerin sosyal medyada siyasete mesafeli olduklarının bir göstergesi olarak kabul edilebilir. Araştırmaya katılan öğrencilerin \%79,9'u sosyal medyada yayınlanan içeriklerin siyasal tercihlerini etkilemediğini belirtmişlerdir. Buradan anlaşllan öğrencilerin siyasal tercihlerini etkileyen daha başat unsurların var olduğu gerçeğidir.

Tüm bu sonuçlar göz önüne alındığında son olarak elde edilenler şu şekilde derlenebilir;

Araştırmaya katılan öğrenciler interneti yoğun bir sıklıkla kullanmaktadırlar. İnterneti de özellikle sosyal medya araçları için kullanmakta, sosyal medya araçlarında ciddi bir 
zaman harcamaktadırlar. Siyasal iletişimde sosyal medya platformları araștırmaya katılan öğrenciler açısından önemli bir iletişim aracı olarak görülmektedir. Öğrencilerin sosyal medyayı yoğun şekilde kullanmalarına rağmen sosyal medyada yer alan siyasal içerikli mesajlara mesafeli yaklaştıkları görülmektedir. Öğrenciler genel olarak sosyal medyayı gençlere ulaşmada etkili bir araç olarak görmektedirler. Araştırmamızda elde edilen bir diğer önemli bulgu da ankette gençlere ulaşmada en etkili araç "sosyal medya" olarak ifade edilmesine rağmen araştırmaya katılan öğrencilerin siyasi konuları en çok geleneksel kitle iletişim araçlarından televizyondan takip ettikleri, bunun yanında sosyal medyadan çok küçük bir oranda siyasi olayların takip edildiği görülmüştür. $\mathrm{Bu}$ da bize sosyal medyanın güvenilirliği hususunda ankete katılan gençlerin tereddütleri olabileceği ihtimalini düşündürmüştür.

Araștırmamızın bizce en önemli sonucu şudur: Sosyal medya platformları gençlere ulaşmada kullanılabilecek en etkili yöntem olarak öne çıkmaktadır. Ancak bununla beraber araştırmamıza katılan gençlere göre sosyal medyadan yayınlanan siyasal içerikler gençlerin fikirlerini belirlemede çok az etkiye sahiptir. Dolayısıyla burada önemli bir ayrımdan söz edilebilir, sosyal medya platformları gençlere mesajlarını ulaştırmak için bir platform olmakla beraber, bu platformdan ulaştırılan mesajların gençler üzerindeki etkisi son derece sınırlıdır. Bu konu da bizce ayrıca araştırılmaya muhtaç bir konudur. Acaba gençler sosyal medyadan gelen siyasal içerikli mesajlara niçin itibar etmemektedir? Burada sosyal medyada birçok yalan haberin hızla yayılması mı etkilidir? Yoksa başka unsurlar mı söz konusudur?

Bütün bu çalışmadan elde edilen bulgulardan yola çıkarak şu konular hakkında araștırma yapılması alana önemli katkı sağlayacaktır.

- Gençler niçin sosyal medya platformlarında siyasal görüşlerini paylaşmama eğilimindedir?

- Gençlerin sosyal medyada siyasal görüşlerini özgürce ifade etmeleri için neler yapılabilir?

- Siyasi partiler ve aktörler gençlere sosyal medya üzerinden ulaşmak için ne yapabilir?

\section{Kaynakça}

Aydın, İ. (2016). Üniversite Öğrencilerinin Sosyal Medya Kullanımları Üzerine Bir Araştırma: Anadolu Üniversitesi Örneği, Selçuk Üniversitesi Sosyal Bilimler Enstitüsü Dergisi, 35, 373-386, Konya

Akar, E. (2015). İnternetle Değişen Siyaset Pazarlaması: Dünyadan Örneklerle Yeni Trendler. Dumlupınar Üniversitesi Sosyal Bilimler Dergisi,(23), https://dergipark. org.tr/tr/pub/dpusbe/issue/4765/65491

Barnlaud, D. (1968). Interpersonal Cummuncation:Survey and Studies, Boston

Behnke, P. (2010). Social Media and Politics Online Social Networking and Political Communication in Asia, Konrad-Adenauer-Stiftung

Bostancı, M. (2014). Siyasal İletişim 2.0, Erciyes İletişim Dergisi, Cilt:3, Sayı:3 ss(84-96), Kayseri

Delany, C. (2009). Learning from Obama Lessons for Online Communicators in 2009 and Beyond, http://www.epolitics.com/learning-from-obama.pdf 
Gerbner, G. (1967). Mass Media and Human Communication Theory, New York

Gülcan, Z. ,Vurgun, Ş. ,Gürdin, B. , Akpınar, M. (2015). Meslek Yüksekokulu Öğrencileri ve Sosyal Ağlar: Nazilli, Atça ve Kuyucak Meslek Yüksekokullarının Karşılaştırması, Electronic Journal of Vocational Colleges, Aralık UMYOS Özel Sayısı, Kırklareli

İnal, A. (1999). Dil ve İktidar Sorunu, Gazi Üniversitesi İletişim Fakültesi Akademik Dergisi, Ankara

Kamp, M. (2016). Assessing the Impact Of Social Media on Political Communication and Civic Engagement in Uganda

Karlsen, R and Enjolras, B. (2016) Styles of Social Media Campaining and Influence in a Hybrid Political Communication System: linking Candidate Survey Data with Twitter Data, The International Journal of Press and Politics, Vol:21(3), p.338-357

Kırık, A. (2013). Yeni Medya Çağı Çerçevesinde Türkiye'de Televizyondan İnternete Dönüşüm ve Sosyal Paylaşım Ağlarında Gençlerin Konumu, Marmara Üniversitesi Sosyal Bilimler Enstitüsü Doktora Tezi, İstanbul

Küçükali, A. (2016). Üniversite Öğrencilerinin Sosyal Medya Kullanımı: Atatürk Üniversitesi Örneği, Bartın Üniversitesi İ.I.B.F Dergisi, Cilt:7, Sayı:13, Bartın

Lakkysetty, N. Deep, P. and Balamarugan, J. (2018). Social Media and Its Impacts on Politics, International Journal of Advance Research, Ideas and Innovations in Technology, Volume:4, Issue:2, pp.2108-2117

Richard, L and Pomper, G. (2002) Effectiveness of Negative Campaigning in US Senate Elections. American Journal of Political Science. 46 (1), pp.47-66

McNair, B. (2011), An Introduction to Political Communication, Taylor and Francis Group. Abingdon

McQuail, D ve Windahl S. (1982) Communication Models for he Study of Mass Communication, Çev. Yumlu, K. (2005). İletişim Modelleri Kitle İletişim Çalışmalarında, İmge Kitapevi, Ankara

Meti, V. (2014). Political Communication in Digital Age - Social Media Analysis.

Mutlu, E. (1994). İletişim Sözlüğü, Ayraç Kitapevi, Isparta

Nulty, P., Teocharis, Y., Sebastian, P., Parnet, O., Benoit, K. (2016). Social Media and Political Communication in the 2014 Elections to the European Parliament, Electoral Studies, Volume:44, pp. 429-444

Osgood, C. E, Suci, G. J. ve Tannenbaum, P. H. (1957). The Measurement of Meaning, University of Illinois Press, Urbana.

Safko, L. and Brake, D. (2009). The Social Media Bible Tactics Tools and Strategies for Business Success, John Wiley\&Sons Inc, New Jersey

Safko, L. (2010). The Social Media Bible Tactics Tools and Strategies for Business Success, John Wiley\&Sons Inc, New Jersey

Salvatore, A. (2013). New Media, the "Arab Spring," and the Metamorphosis of the Public Sphere: Beyond Western Assumptions on Collective Agency and Democratic Politics, Constellations Volume 20, No 2, ss. 217-228 
Shami, S. and Ashfaq, A. (2018). Strategic Political Communication, Public Relations, Reputation Management \& Relationship Cultivation through Social Media, Journal of Research Society of Pakistan, Volume:55, Issue:2, pp.139-154

Solmaz, B , Tekin, G , Herzem, Z , Demir, M . (2013). İnternet Ve Sosyal Medya Kullanımı Üzerine Bir Uygulama. Selçuk İletişim , 7 (4) , 23-32

Stieglitz, S., Brockmann, T. And Xuan L. D.(2012). Usage Of Social Media For Political Communication, PACIS.

Svanson, D. And Nimmo, D. (1990). New Directions in Political Communication;A Research Book, Newbury Park

Topuz, H. (1991). Siyasal Reklamcılık: Dünyadan ve Türkiye'den Örneklerle, Cem Yayınevi, İstanbul

Uslu, Z. K. (1996). Siyasal İletişim ve 24 Aralık 1995 Genel Seçimleri, Yeni Türkiye Dergisi, Sayı:11, Ankara

Üksel, S. (2015). Kullanımlar ve Doyumlar Kuramı Çerçevesinde Sosyal Medya Kullanımı: Sakarya Üniversitesi Öğrencileri Üzerine Bir Araştırma, Selçuk Üniversitesi Sosyal Bilimler Enstitüsü Yüksek Lisans Tezi, Konya

Theodorson, S. A. Ve Theorson, A. G. (1969). A Modern Dictionary of Sociology, Cassell, New York

Wolfsfeld, G., EladSegevand T. S. (2013) Social Media and the Arab Spring: Politics Comes First, http://hij.sagepub.com/content/early/2013/01/16/1940161212471716

Yavaşgel, E. (1997). Siyasal İletişim Kuramı, İstanbul Üniversitesi İletişim Fakültesi Dergisi, Cilt:0 Sayı:4, s.219-233 


\title{
The Reactions of University Students on Political Messages In Social Media Platforms; A Quantitative Research at the Duzce University Vocational School of Social Sciences
}

\author{
Ömer Faruk Özgür (Lect. Ph.D.)
}

\section{Extended Abstract}

Social media and Internet has entered our lives with the advent of new communication technologies, and while especially becoming the core of young adults' lives, has longly been accepted by almost all the world. Various researches show that young people are increasingly using social media intensive for self presentation, interpersonal communication, to get daily news and to express their ideas. Internet and social media are used in many fields of activity. One area where it is used very intensively is the area of "political communication". Politicians reach the voters through the traditional media, as well as through social media platforms. Some of the reasons why social media channels are preferred by politicians are: Intensive use of social media by young people, promoting advertising and advertising costs in social media with lower budgets than traditional media, providing easier access to target audience through social media, social media provide politicians with the opportunity to dialogue with voters. Aim of the Study: This research aims to reveal the internet and social media usage practices of university students and also to explore their approach to various political posts seen on social media platforms in relation with this context. For this purpose, a sample of 420 students from Düzce University Social Sciences Vocational School were included in the study and a questionnaire survey was conducted with this group. Method: In the scope of the study, face-to-face survey technique was used as a quantitative research method. The study was conducted with 98\% confidence level and 5\% error margin. Findings: Social media in political communication is seen as an important tool by the students, though they appear to be distant from political messages in the social media, and more than half of the young adults are likely followers instead of commenting and engaging with the shared posts. Although findings of the research can not be generalized for all university students, this pilot study has the potential to provide meaningful data on young people's social media practices and behaviors towards political communication. Students participating in the research use the internet frequently. They also use the Internet especially for social media tools and spend a lot of time on social media. $65.2 \%$ of the students who participated in the research stated that they did not follow the person or the page regarding any political opinion in social networks. This may be considered as an indicator of the distance of the students to politics in social media. $79.9 \%$ of the students who participated in the research stated that the contents published in social media did not affect their political preferences. It is the fact that there are more prominent elements influencing the political preferences of the students understood. 55.5\% of the students who participated in the research stated that they did not comment on the contents in social media. This shows that the students who participate in the research are more likely to follow the role of a follower. $67.3 \%$ of the students who participated in the study stated that they did not comment on political issues in social networks. In other words, it was concluded that the students were abstaining about sharing their views on political issues. The students who participated in the research frequently use the internet. They also use the internet especially for social media tools and spend a considerable time in social 
media tools. Social media is seen as an important tool for political students in political communication. Although the students use social media extensively, it is seen that they approach distance from political messages in social media. Students generally see social media as an effective means of reaching out to young people. Another important finding obtained in our study was that although the most effective tool for reaching young people was called social media, it was seen that the students who participated in the research followed the political issues mostly from the traditional mass media on television, and a small percentage of the political events were followed from the social media. This makes us think that there may be doubts about the reliability of social media.

In our opinion, the most important result of our research is as follows: Social media platforms stand out as the most effective method to reach young people. However, according to the youth participating in our research, political content published on social media has little effect on determining the opinions of young people. Therefore, an important distinction can be made here, although social media platforms are a platform for conveying their messages to young people, but the impact of these messages on young people is very limited. In our opinion, this issue is also an issue that needs research. Why do young people disregard political messages from social media? Is the rapid spread of many false news here on social media effective? Or are there other elements?

Keywords: Social Media, University Students, Political Posts, Internet Usage, Political Communication. 